\title{
Karol Dobrzeniecki, Prawo wobec sytuacji nadzwyczajnej. Między legalizmem a koniecznością, Toruń 2018. Recenzja
}

Praca prof. Karola Dobrzenieckiego dotyczy zagadnienia nierozpoznanego dotąd w polskiej literaturze filozoficzno- i teoretycznoprawnej, a mianowicie możliwości pozytywno-prawnego ujęcia sytuacji szczególnych, zagrażających bytowi wspólnoty politycznej, których cechy z istoty rzeczy nie mogą być w pełni wyartykułowane w hipotezach norm prawnych. W rozdziale pierwszym autor wprowadza klarowne rozróżnienie na sytuację wyjątkową, tj. stan faktyczny wymagający podjęcia działań przez prawo nieprzewidzianych lub nawet z nim niezgodnych - i stan wyjątkowy, tj. hipotezę normy prawnej. Podstawowym celem pracy jest analiza relacji między ujmowaniem sytuacji wyjątkowej wyłącznie w kategoriach pozytywno-prawnych, czyli jako stanu wyjątkowego - a jej ujęciem jako zagadnienia politycznego i moralnego. Autor na każdym etapie swoich rozważań wyraża obawy przed swoistą „kolonizacją” sytuacji wyjątkowej przez prawo pozytywne, co może doprowadzić do, jak to określa, „normalizacji” stanu wyjątkowego, przeniknięcia jego specyficznych rozwiązań do prawa przeznaczonego dla sytuacji zwyczajnych, a przez to zanik rozróżnienia na sytuację zwyczajną i wyjątkową. Alternatywą ma być uznanie przez prawo pozytywne ograniczonej możliwości uregulowania sytuacji nadzwyczajnej, a przez to (z pozytywistycznego punktu widzenia będzie to paradoks) wyraźne wyodrębnienie przypadków nadzwyczajnych, w których normy prawne, nawet te chroniące istotne prawa jednostek, muszą schodzić na dalszy plan - od sytuacji zwyczajnych, w których powinny być bezwzględnie przestrzegane. Kategorią, która ma umożliwiać dostrzeganie przez prawo własnej ograniczoności jest kategoria konieczności, swoista metoda „odczytania” przez system prawny sytuacji, która wychodzi poza jego granice.

Taki dobór przedmiotu i celu rozważań decyduje o tym, że niewystarczające byłoby odwołanie się wyłącznie do problematyki prawa pozytywnego, dogmatyki prawnej czy nawet teorii i filozofii prawa. Konieczne jest, jak trafnie zauważa K. Dobrzeniecki, uwzględnienie dorobku teorii i filozofii polityki, co autor ten czyni.

1 Numer ORCID: 0000-0002-9347-7072. Adres e-mail: abarut@wp.pl 
Rozważania szczegółowe można podzielić na dwa bloki problemowe, wzajemnie ze sobą powiązane i odpowiadające dwuaspektowemu tematowi pracy. W rozdziałach 2-4 autor analizuje prawne interpretacje sytuacji wyjątkowej. Z kolei w rozdziałach 5-6 prawne interpretacje kategorii pozaprawnej, a więc konieczności.

Karol Dobrzeniecki w rozdziale drugim wychodzi od alternatywnej wobec współczesnego konstytucjonalizmu tradycji myślenia o sytuacji wyjątkowej, tj. od klasycznej myśli filozoficznoprawnej. Szczególną uwagę poświęca tradycji arystotelesowsko-tomistycznej, liberalizmowi epoki wczesnonowożytnej oraz współczesnemu decyzjonizmowi zarówno konserwatywnemu, jak i ponowoczesnemu. Autor wskazuje na różnice między klasyczną myślą prawną a myśleniem w kategoriach pozytywistycznych, które to różnice ujawniają się z perspektywy rozważań nad sytuacją wyjątkową. Na gruncie pierwszej z tych tradycji prawo było pojmowane jako część dyskursu praktycznego określonej wspólnoty politycznej i korzystało z uzasadnienia „nadjednostkowego” (ontologicznego). Dzięki temu refleksja nad prawem mogła dostrzec ograniczenia stojące przed ustawodawcą i sędzią oraz była otwarta na argumentację z dziedziny filozofii moralnej, filozofii polityki, socjologii i antropologii filozoficznej. Poprzez kategorie dyspensy i słuszności, a także przez takie instytucje jak rzymskie iustitium, klasyczne rozumienia prawa umożliwiało uchwycenie, przynajmniej w pewnym stopniu, specyfikę sytuacji wyjątkowej. Tę klasyczną tendencję autor dostrzega również w sformułowanej przez Johna Locke'a koncepcji prerogatywy, stanowiącej antytezę swoistego prawnego „imperializmu", który najpełniejszy wyraz znalazł w filozofii Immanuela Kanta. Obecnie, w kompletnie przeobrażonym kontekście filozoficznym, klasyczne rozumienie sytuacji nadzwyczajnej wyraża konserwatywny decyzjonizm, w szczególności zaś koncepcja Carla Schmitta. K. Dobrzeniecki, daleki zarówno od idealizowania tej postaci, jaki i od uzgadniania „na sifę” koncepcji C. Schmitta z liberalnym konstytucjonalizmem, uwydatnia aksjologiczne umocowanie decyzjonizmu autora Teologii politycznej. Z kolei odwołania do ponowoczesnych interpretatorów, a zarazem krytyków C. Schmitta, takich jak Walter Benjamin i Giorgio Agamben interpretujących stan wyjątkowy z pespektywy filozoficzno-antropologicznej, służą do uwydatnienia niebezpieczeństwa jego normalizacji.

Rozdział trzeci dotyczy ujmowania sytuacji wyjątkowej na gruncie liberalnej myśli polityczno-prawnej, czyli, jak to określa autor, liberalnego konstytucjonalizmu². Autor z pieczołowitością i hermeneutyczną życzliwością (mówiąc językiem Hansa-Georga Gadamera: „z założeniem doskonałości”) analizuje liberalne filozofie i doktryny prawne, a także inspirowane przez nie uregulowania prawa konstytucyjnego, międzynarodowego i ponadnarodowego. Czyni to w poszukiwaniu kategorii adekwatnych do specyfiki sytuacji wyjątkowej, których przyjęcie zapobiegałoby „rozlaniu się” stanu wyjątkowego na całość systemu prawnego. K. Dobrzeniecki dostrzega leżący u źródeł współczesnego liberalnego konstytucjonalizmu woluntaryzm, do którego sprowadza się również rzekomy racjonalizm oświecenia. Autor zaczyna analizę od pierwszej rozwiniętej liberalnej koncepcji uzasadniającej zawieszanie obowiązywania podstawowych praw jednostki w sytuacji zagrożenia bytu wspólnoty politycznej, tj. od idei Clintona Rossitera. Jej egzegeza jest wstępem do wyartykułowania nierozwiązywalnych z liberalnego punktu widzenia paradoksów, w które wikła się myśl liberalna, gdy chce uzasadnić sposób działania władzy politycznej w sytuacji nadzwyczajnej, a zarazem pozostać na gruncie

Na marginesie warto zauważyć, że posługiwanie się pojęciem liberalnego konstytucjonalizmu, a nie np. konstytucjonalizmu tout court jawi się jako podkreślenie politycznego uwarunkowania najbardziej nawet „klasycznych” koncepcji prawnych. 
jednego z podstawowych założeń demokratyczno-liberalnych, tj. uznawania prawa pozytywnego spełniającego „test” zgodności z prawami człowieka za najważniejszą gwarancję interesów jednostki.

Pierwszy paradoks („egzystencjalny”) wyraża się w pytaniu, w jaki sposób samo prawo może zakładać, że wolno je złamać w imię obrony wspólnoty politycznej - wartości choć przez prawo chronionej, to jednak pozaprawnej. Przejawem drugiego paradoksu są wątpliwości, czy prawo może przewidzieć i uregulować to, co samo uznaje za nieprzewidywalne. Trzeci paradoks wyraża się w problemie przesłanek samoograniczania się prawa, które ma być zarazem - jako wyraz woli powszechnej ujętej w formy sprawiedliwości formalnej - samowystarczalną instytucją niepotrzebującą uzasadnienia ze strony „rozległych doktryn”. Następnie autor rekonstruuje typy prawnego ujmowania sytuacji nadzwyczajnej. Pierwszy z nich to typ legislacyjny, polegający na próbie antycypacji sytuacji nadzwyczajnej w normach prawnych. Drugim typem jest uznanie takiej sytuacji jako Dworkinowskiego hard case, którego rozstrzygnięcie wymaga wieloaspektowego - nie tylko stricte jurydycznego, ale również moralnego - spojrzenia, a także kierowania się zasadą politycznej odpowiedzialności. Nie ma wątpliwości, że według K. Dobrzenieckiego to drugie podejście jest właściwe. Analizy autora wskazują, że współczesne koncepcje liberalne nie tylko nie przynoszą zadowalających rozwiązań powyższych paradoksów, lecz ponadto pojawia się tendencja, aby przechodzić nad nimi do porządku dziennego. Odpowiedzią na paradoks egzystencjalny ma być uniwersalizacja liberalnego modelu stanu wyjątkowego, a reakcją na paradoks suwerenności ludu ,jurydyzacja sytuacji nadzwyczajnej połączona z kształtowaniem nawyku posłuszeństwa wobec prawa, krępującego pozaleganą aktywność obywateli”’3. Autor stwierdza postępującą jurydyzację sytuacji nadzwyczajnej, która wiąże się z uznaniem prawa stanu wyjątkowego za normalny stan prawa państwa demokratyczno-liberalnego. Jurydyzacja ta ujawnia swoje szkodliwe następstwo, tj. wypieranie uzasadnienia moralnego na rzecz uzasadnienia pozytywno-prawnego. Na skutek tego prawo jawi się jako medium zbanalizowane - co nie znaczy, że mniej niebezpieczne. Można skonkludować, że szczegółowo analizowany przez autora dorobek prawa konstytucyjnego dotyczący mechanizmów derogacyjnych wydaje się mieć coraz mniejsze znaczenie praktyczne, jeśli bowiem całe prawo staje się prawem stanu wyjątkowego, to z definicji nie ma już sytuacji nadzwyczajnych.

W kolejnym rozdziale Interpretacja zasady rzadów prawa w kontekście wojny z terroryzmem autor wyróżnia trzy występujące w jurysprudencji, ustawodawstwie i praktyce prawa podejścia do współczesnych sytuacji nadzwyczajnych związanych z zagrożeniem terrorystycznym: absolutyzm konstytucyjny, konstruowanie modeli adaptacyjnych oraz podejście godzące się na permanentny stan nadzwyczajny. Absolutyzm konstytucyjny zakłada, że właśnie w sytuacji nadzwyczajnej szczególnie istotne jest pieczołowite przestrzeganie wszelkich norm chroniących jednostkę i „korygowanie” w ten sposób przez sądy szczególnych unormowań wprowadzanych przez legislatywę i egzekutywę. Można powiedzieć, że wówczas następuje jurydyzacja sytuacji nadzwyczajnej poprzez swoiste „wyparcie” jej nadzwyczajności (zaznaczam, że autor takiej tezy nie formułuje). W modelach adaptacyjnych deklaruje się wolę zachowania podstawowych wartości konstytucyjnych w nowej, dramatycznej sytuacji, przy użyciu odmiennych środków prawnych. Permanentny stan wyjątkowy jest wynikiem rozwoju technologii, która stwarza władzy nieograniczone możliwości inwigilacji i „prewencji”, a także „uzwyczajnienia” środków,

K. Dobrzeniecki, Prawo wobec sytuacji nadzwyczajnej. Między legalizmem a koniecznościa, Toruń 2018, s. 179. 
które miały służyć jedynie czasowo do obrony systemu demokratyczno-liberalnego. Karol Dobrzeniecki wskazuje na nadużycia, które wiążą się w ujmowaniem sytuacji nadzwyczajnej wyłącznie w kategoriach pozytywno-prawnych takie jak stosowanie wykładni rozszerzającej w celu uzasadnienia zwiększenia kompetencji organów państwowych, a wykładni zwężającej do uzasadnienia ograniczenia praw jednostki. W świetle poglądów autora jest jasne, że nie ma on nic przeciwko poszukiwaniu umocowania prawno-konstytucyjnego dla nieprzewidzianych przez prawo pozytywne działań władzy podejmowanych dla dobra publicznego. Niewątpliwie jednak jego opory budzi „wywodzenie” łamanie standardów prawnych z norm prawnych, na podobieństwo uzasadniania „aktywistycznych" orzeczeń sądowych w sytuacji zwyczajnej. Stanowisko K. Dobrzenieckiego należy usytuować miedzy absolutyzmem a modelem adaptacyjnym. W szczególności wydaje się mu być bliskie podejście do problemu aktywizmu przedstawione przez Cassa Sunsteina, zakładające kontrolowanie przez sędziego realizacji standardów ochrony praw jednostki jedynie na potrzeby konkretnego przypadku (w sposób „powierzchowny i ścisły”), bez ulegania pokusie „naprawiania” systemu prawnego.

Rozdział piąty autor rozpoczyna od zrekonstruowania podejścia do kategorii konieczności w klasycznej filozofii prawa oraz w prawie wczesnonowożytnym (problem „deski Karneadesa” i tym podobne zagadnienia). Następnie przechodzi do omówienia interpretacji kategorii konieczności we współczesnej teorii i filozofii prawa. W rozdziale tym autor formułuje ciekawą propozycję teoretycznoprawnego ujęcia kategorii konieczności, tj. interpretowania działań władzy w sytuacji nadzwyczajnej jako analogonu nieposłuszeństwa obywatelskiego. Byłyby to więc działania naruszające normy prawne, lecz podejmowane w celu ochrony prawa, wraz z gotowością poddania się ocenie prawnej, gdy sytuacja wyjątkowa się skończy. W wywodach autora widoczny jest zamiar uwydatnienia tragicznej pozycji piastunów władzy politycznej, zmuszonych do trudnych wyborów moralnych (tzw. koncepcja brudnych rąk za pomocą której interpretowano np. bombardowania Niemiec i Japonii w okresie II wojny światowej), a także sytuacji obywateli chcących ratować swoją wspólnotę. Tragizm ten zatraca się w razie apriorycznego zrównania sytuacji nadzwyczajnej ze stanem wyjątkowym. Na podobnych przesłankach wydaje się być oparty analizowany przez autora „model środków pozaleganych” Orena Grossa. Koncepcja ta sięga do Locke'owskiej idei prerogatywy jako prawnego umocowania działań przekraczających czy łamiących prawo. Według O. Grossa działania te, aby mogły być uznane za dopuszczalne środki pozalegalne, muszą być podejmowane jedynie w stanie najwyższej konieczności, przedstawione współobywatelom jako środki naruszające prawo, zaś podmiot je stosujący musi być gotowy poddać się ex post kontroli swych działań. K. Dobrzeniecki wskazuje na liczne głosy krytyki, które ta koncepcja sprowokowała, a zarazem na jej zaletę: koncepcja ta nie zakłada (tak samo jak propozycja autora) zmiany systemu prawnego i nie „podstawia” pod zwykłe uregulowania uregulowań nadzwyczajnych. Nie można jednak nie oprzeć się wrażeniu, że O. Gross, odwołując się (jak to pokazuje autor) do tradycji liberalnego konstytucjonalizmu i autorytetów prawniczych, chce jednak postawić na dalszym planie pozaprawny charakter środków, które proponuje. Propozycja samego K. Dobrzenieckiego, tylko ogólnie zarysowana w monografii, wydaje się mniej narażona na ten zarzut.

Rozdział szósty dotyczy sposobu ujmowania konieczności w prawie pozytywnym: karnym, konstytucyjnym i międzynarodowym. Z kolei w zakończeniu autor wskazuje na teoretyczną płodność problematyki sytuacji nadzwyczajnej. Podkreśla potrzebę przezwyciężenia marginalizacji tej problematyki, niełatwo wpisującej się w liberalny 
konstytucjonalizm, a także uporządkowania związanej z nią terminologii. Autor zauważa, że właśnie problematyka sytuacji nadzwyczajnych pozwala dostrzec, iż kluczowy spór we współczesnej filozofii prawa ma miejsce nie tylko na linii pozytywizm-jusnaturalizm, ale również na linii legalizm-decyzjonizm. Autor, szczegółowo i życzliwie analizujący liberalny paradygmat prawny, dostrzega jednak jego granice.

Reasumując, podstawową wartością monografii Karola Dobrzenieckiego jest wieloaspektowe i metodologicznie staranne przeanalizowanie problematyki sytuacji nadzwyczajnej i stanu wyjątkowego dokonane z perspektywy rozdzielenia tych dwóch kategorii oraz uwydatnienie zagrożeń, jakie rodzi jurydyzacja sytuacji nadzwyczajnej. Autor nie pomija w zasadzie żadnego aspektu analizowanego problemu. Można ewentualnie dodać, że przyczyn trudności, jakie liberalizm ma ze skonceptualizowaniem sytuacji nadzwyczajnej, warto byłoby poszukać w jego najgłębszych, filozoficznych założeniach. Mowa tu o odejściu od substancjalnie rozumianej tożsamości osoby ludzkiej, które dzisiaj ujawnia w szczególności proliferacja praw człowieka: dekonstrukcja praw dotąd uznanych i ciagłe konstruowanie praw nowych, zgodnie z postulatami walki o przemiany polityczno-kulturowe. Gdy tożsamość, a przez to prawa jednostki, stają się kwestią woli, czyli umowy lub gry aktorów władzy, nie ma przeszkód, by je realizować za pomocą instrumentów stanu wyjątkowego. Jest to jednak moje osobiste przekonanie, które oczywiście nie powinno mieć przełożenia na ocenę monografii. Podkreślić należy, że autor konstruuje przejrzystą terminologię, a dyskurs prowadzi klarowanie i interesująco. Imponująca jest też baza źródłowa, z której korzystał autor. Praca ma dzięki temu wartość stricte poznawczą: K. Dobrzeniecki prowadzi czytelnika przez skomplikowaną mozaikę współczesnych koncepcji prawnych i politycznych, a także ustawodawstwa i praktyki orzeczniczej, dokładnie je rekonstruując i analizując.

Monografia Prawo wobec sytuacji nadzwyczajnej. Między legalizmem a koniecznościq jest moim zdaniem obowiązkową pozycją nie tylko dla filozofa i teoretyka prawa, lecz również teoretyka polityki. Będzie także użyteczna dla badaczy zajmujących się dogmatyką prawną oraz naukami politycznymi w aspekcie empirycznym. 